\title{
Significance of Allotment Gardens in Urban Green Space Systems and Their Classification for Spatial Planning Purposes: A Case Study of Poznań, Poland
}

\author{
Dominika Dymek ${ }^{1}\left(\mathbb{D}\right.$, Agnieszka Wilkaniec $^{1}{ }^{\circledR}$, Leszek Bednorz ${ }^{1}\left(\mathbb{D}\right.$ and Magdalena Szczepańska ${ }^{2, *}$ \\ 1 Faculty of Agronomy, Horticulture and Bioengineering, Poznań University of Life Sciences, \\ 60-637 Poznań, Poland; ddymek89@gmail.com (D.D.); agnieszka.wilkaniec@up.poznan.pl (A.W.); \\ leszek.bednorz@up.poznan.pl (L.B.) \\ 2 Faculty of Human Geography and Planning, Adam Mickiewicz University in Poznań, 61-680 Poznań, Poland \\ * Correspondence: szmagda@amu.edu.pl
}

\section{check for}

updates

Citation: Dymek, D.; Wilkaniec, A.; Bednorz, L.; Szczepańska, M. Significance of Allotment Gardens in Urban Green Space Systems and Their Classification for Spatial Planning Purposes: A Case Study of Poznań, Poland. Sustainability 2021, 13, 11044. https://doi.org/10.3390/ su131911044

Academic Editor: Richard Ross Shaker

Received: 29 August 2021

Accepted: 3 October 2021

Published: 6 October 2021

Publisher's Note: MDPI stays neutral with regard to jurisdictional claims in published maps and institutional affiliations.

Copyright: (c) 2021 by the authors. Licensee MDPI, Basel, Switzerland. This article is an open access article distributed under the terms and conditions of the Creative Commons Attribution (CC BY) license (https:/ / creativecommons.org/licenses/by/ $4.0 /)$.
Abstract: Almost five thousand allotment gardens divided into one million plots are used by roughly $10 \%$ of Polish society. Several studies have emphasized their social importance and significance for enlargement of the area and the integrity of urban spatial greenery systems. However, the area of allotment gardens in Polish cities has been decreasing since the changes in the post-communist country in the 1990s. There is a lack of a simple method of classification and valuation of allotment gardens in relation to their significance in urban green space systems that could be used by officials and city planners. Hence, this study aims to examine the significance of allotment gardens in the spatial development of the green space system of Poznan and classify them with a simple and universal method of valuation which could be used in urban planning. The location of allotment gardens in the urban green space system in Poznan was examined with the classification method elaborated here. It was based on the valuation of several internal and external features of individual allotment gardens. The results showed that allotment gardens are important areas and spatial elements of the green space system in Poznań. Over 30\% of allotment gardens are of high significance in the green space system of the city. Nevertheless, according to urban planning documentation, there are plans to reduce the area of allotments in Poznań. Even gardens indicated in the research to be of high significance to the integrity and enlargement area of the urban green space system are planned to be liquidated. Use of the developed classification could influence the decision-making process regarding the liquidation of allotment gardens and preserve the most valuable objects.

Keywords: land use; urban agriculture; urban greenery; urban planning; sustainable landscape

\section{Introduction}

Providing adequate areas of well-functioning green space systems is a basic way of developing the urban spatial structure [1]. An urban greenery system is an arbitrary conceptual unit covering green spaces in a city. It is arranged in a certain organizational system, usually referring to the urban composition; it is contractual because it is characterized as (and should be) a reference to the natural structures of the neighborhood. It is usually extended in open areas in suburban zones and then becomes part of the ecological network on a supra-local scale. Urban green spaces provide numerous ecosystem services for city inhabitants such as cultural services by giving people opportunities to experience nature in the city [2]. These are areas of high social significance used for leisure and recreation [3-5]. They also provide regulating services, reducing air pollution and improving the local climate and quality of the natural environment in cities [6-8]. They regulate surface runoff [9] and contribute to the protection of waters and soils [10]. Furthermore, they provide shelter for various organisms, thus helping to maintain biodiversity, which is a habitat service [11-13], and provide provisioning services such as food supply via allotment gardens and other urban gardening (urban agriculture) examples [14-16]. 
Currently, there are 4601 allotment gardens in Poland with a total area of 40,186.6 ha; this number of gardens consists of 905,900 individual plots [17]. It is estimated that a single plot is used by 3-4 people, which means that 3-4 million people directly use green space in allotment gardens in Poland [18,19]. Lewińska [20], Pawlikowska-Piechotka [21] and Kronenberg et al. [22] emphasized the importance of allotment gardens for the natural environment in cities, especially due to the fact that they are wildlife corridors connecting urban green spaces, whose continuity and internal diversity determine their ability to effectively provide ecosystem services. According to Kronenberg et al. [22], the role of allotment gardens in cities is underestimated because it is incorrectly identified only with the interests of a narrow group of their direct users. However, both allotment garden users and other city dwellers benefit from these areas as they provide a wide range of regulatory and basic services [16,22-26]. However, due to the productive and recreational nature of allotment gardens, the supplying of products and provision of cultural services are their most important functions [22,27-29]. They also increase social resilience [23,30,31]. The scientific literature also emphasizes their importance for the spatial arrangement of cities. They can provide functional and structural connectivity of the green spaces in an urban landscape [32]. Allotment gardens can also develop continuous networks of productive open spaces able to connect the city to the rural landscape [33] and complement the system of recreational spaces. Its value is high if it interacts and connects with other green spaces and can be an important part of a city's green infrastructure [32].

The classification of allotment gardens as green spaces is a controversial issue in Poland. According to Article 5 of the Allotment Gardens Act of 13 December 2013 [34], allotment gardens are green spaces. However, this statement was not confirmed by the provisions of the Nature Conservation Act of 16 April 2004 [35], which defines green spaces and provides numerous examples, but without allotment gardens. The reason for this situation could be the specific nature of the management and functioning of allotment gardens. The research carried out by Kacprzak et al. [36] shows that some provisions of legal acts are not strictly followed, and unclear regulations concerning the way of growing crops have led to a shift from the agricultural function to recreational and residential functions. Like in other countries [37], Polish allotment gardens are managed by garden associations - the vast majority being managed by the Polish Association of Allotment Gardeners. Contrary to green spaces, i.e., parks and lawns, these are semi-public spaces with limited access for a wider group of people who are not allotment garden users. It is also important that allotment garden users do not own land in their plots. They only own plants and the garden infrastructure-e.g., sheds, fences and paths-and they use allotment gardens under lease contracts $[16,21]$.

Allotment gardens are usually located in spaces that are attractive for investments; therefore, these areas are vulnerable to functional transformation. Hence, it is important to determine which gardens are the most valuable as part of the urban greenery system and should not undergo functional transformations. To evaluate this, easy-to-use methods are needed that can be practiced not only by scientists but also by officials or city planners. There are proven and effective methods of valuation used in research which can be applied to allotment gardens, but they are sophisticated and require advanced research skills (statistics and strong interpretative skills) [38].

The main objectives of this study were (1) to examine the significance of allotment gardens in the spatial development of the green space system of Poznan (increasing its surface area, improving continuity and accessibility by citizens) and (2) to elaborate a classification of allotment gardens in the urban green space system as a universal and simple method of their valuation which can be used in urban spatial planning. The classification and valuation of allotment gardens could be useful due to plans to liquidate existing allotments and select locations for the new ones. 


\section{Methods}

Poznan $\left(52^{\circ} 24^{\prime} 30.4^{\prime \prime} \mathrm{N}, 16^{\circ} 56^{\prime} 03.4^{\prime \prime} \mathrm{E}\right)$ is the fifth largest city in Poland (over 540,000 inhabitants). The city has a wedge-ring system of green spaces, which was shaped over time. The rings are connected with fortifications, whereas the green wedges run along the three river valleys of the Warta, Cybina and Bogdanka from the external borders to the city center. The main purpose of the wedge system is to protect water and ventilate the city. The wedges form parks in the city center and municipal forests, allotment gardens, meadows and pastures in the outskirts of the city. The green wedge areas are under considerable urbanization pressure. In 2019, the share of green spaces, cemeteries, street greenery and municipal forests in the city area amounted to $17.1 \%$ [17].

The surroundings of allotment gardens in Poznań were analyzed in terms of their function and space to identify their significance in the urban greenery system (in terms of surface area, improving continuity of the greenery system and accessibility by citizens). Analyses were carried out using the program Quantum GIS Desktop 2.18.1 based on data from Urban Atlas [39] and the following planning documents: study of conditions and directions of spatial development (SUiKZP) as well as local plans (MPZP) and satellite images from the period 2001-2016 from the Google Earth Pro platform. From the Google Earth platform and Urban Atlas, spatial data with the current land development of the city were collected; data on functional and spatial structures were also collected from land use planning documents-SUiKZP and MPZP. The following functional and spatial categories were specified: urban greenery, surface waters, main roads, railways, industrial zones, airports and sewage treatment plants. It was assumed that green spaces and surface waters are desirable areas for allotment gardens (increasing the recreational and natural value of the area, marking the continuity of green space systems), and undesirable areas that are a source of noise and pollution include main roads, railways, industrial zones, airports and sewage treatment plants. Three buffers measured from the boundaries of an allotment garden were determined according to the significance, impact strength and intensity of a given variable: $200 \mathrm{~m}$ for urban green spaces and main roads; $300 \mathrm{~m}$ for surface waters; $500 \mathrm{~m}$ for railways, industrial zones and sewage treatment plants and $1000 \mathrm{~m}$ for airports. To determine the size of the buffers, in the case of functions with a positive impact, the concept of the pedestrian access isochrone was used, i.e., the distance related to the time of reaching the tested site and standards used in urban planning practice to maintain good accessibility to green spaces [40]. In the case of functions with a negative impact on allotment gardens, the results presented on Acoustic maps of Poznan (2017), showing the acoustic impact of roads, airports, industrial centers and railway lines on the surroundings and the ranges of impact of these objects marked in maps, were taken into account.

The functional and spatial analysis of the surroundings of Poznan allotment gardens was used as the basis for their classification, where individual gardens were valuated in terms of their significance in the urban green space system in Poznan and the influence of a given allotment garden on the condition of the natural environment in the city. It was assumed that their location in the spatial system of the city, in addition to simply increasing the area of greenery depending on the neighborhood, may increase the continuity of green spaces and improve their social potential (recreational, leisure, educational, productional) [41].

An important factor was the spatial connectivity of allotment gardens with other green spaces, allowing to increase the continuity of the city's green system and enlarging its area. Due to the fact that urban green spaces are in the vicinity of all allotment gardens in Poznań, their location was taken as an important feature of allotment gardens in relation to green wedges, which are the most important element of the spatial structure of the city's green system. Increasing the area of green wedges is also important in view of the strong urbanization pressure on them [42]. The surface waters category was extended by waterbodies and watercourses located within or at $300 \mathrm{~m}$ from allotment gardens. Apart from these two functional and spatial categories, the age of the gardens and their areas were also included in the analyses. It was assumed that the longer the garden had existed, 
the higher the chance was of there being valuable old trees as part of its greenery and more diverse and rich environments. It was assumed that larger allotment gardens are more resistant to the influence of negative factors and create a more stable, balanced and sustainable ecosystem.

The selected valuation variables were divided into two groups: internal variables, such as the age and area, and external ones, such as the location in relation to the green spaces system, surface waters, main roads, railways, industrial zones, airports and sewage treatment plants. The external valuation variables were assigned a value on the following scoring system: $-4,-2,-1,0,1,2,4$. If the valuated variable was highly significant for the attractiveness and potential role of allotment gardens in the city space structure, it was rated either -4 or 4 , depending on its influence on a specific criterion. Less important variables were rated either -2 or 2 , depending on their influence on a specific criterion. If a particular variable occurred only partially, the score was divided by two, e.g., -2 or 2 , for very significant variables or -1 or 1 for variables of less significance, depending on their influence on a specific criterion. If a highly significant valuated variable occurred only episodically, it was rated -1 or 1 , depending on its influence on the classification criterion under analysis.

Negative points were given to the categories that negatively influenced a typological criterion of the allotment gardens under analysis: main roads, railways, industrial zones, airports and sewage treatment plants as a source of pollution, noise or odors, negatively affecting the quality of the environment and the recreational attractiveness of allotment gardens. Positive points were awarded to the categories that positively influenced the criteria of allotment gardens under analysis: green spaces system (green wedges) and surface waters (Table 1).

Table 1. Ranges of points refer to characteristic features of allotment gardens.

\begin{tabular}{|c|c|c|}
\hline Characteristic Features & Ranges & Points \\
\hline \multicolumn{3}{|l|}{ Internal } \\
\hline \multirow{5}{*}{ Age (years) } & $0-20$ & 1 \\
\hline & $21-40$ & 2 \\
\hline & $41-60$ & 3 \\
\hline & $61-80$ & 4 \\
\hline & Over 81 & 5 \\
\hline \multirow{4}{*}{ Area (ha) } & Up to 2 & 1 \\
\hline & $2.1-5$ & 2 \\
\hline & $5.1-20$ & 3 \\
\hline & Over 20 & 4 \\
\hline \multicolumn{3}{|l|}{ External } \\
\hline \multirow{4}{*}{ Relation to urban green system } & $\begin{array}{l}\text { Allotment garden located outside an urban greenery system (green } \\
\text { wedges in Poznań), not connected with other green spaces }\end{array}$ & 0 \\
\hline & $\begin{array}{l}\text { Allotment garden located outside an urban greenery system (green } \\
\text { wedges in Poznań), connected with other green spaces }\end{array}$ & 1 \\
\hline & $\begin{array}{l}\text { Allotment garden located partly within the urban greenery system } \\
\text { (green wedges in Poznań) or connected to other green spaces }\end{array}$ & 2 \\
\hline & $\begin{array}{c}\text { Allotment garden located entirely within the urban greenery } \\
\text { system (green wedges in Poznań) }\end{array}$ & 4 \\
\hline \multirow{2}{*}{ Surface waters } & Allotment garden without surface waters within $300 \mathrm{~m}$ & 0 \\
\hline & Allotment garden with surface waters within $300 \mathrm{~m}$ & 2 \\
\hline Negative pressure of surrounding & $\begin{array}{l}\text { Main roads, railways, industrial zones, airports and sewage } \\
\text { treatment plants as a source of pollution, noise or odors }\end{array}$ & $\begin{array}{c}-4 \\
-2 \\
-1 \\
0\end{array}$ \\
\hline & Maximum number of points & 17 \\
\hline
\end{tabular}


Each allotment garden could score a maximum of 17 points. This number was divided into 4 ranges, defined as 4 classes.

The four classes in the classification system are as follows:

- Class I (very high significance in city green space system): 15 points or more;

- Class II (high significance in city green space system): 10-14 points;

- Class III (low significance in city green space system): 5-9 points;

- Class IV (very low significance in city green space system): 4 points or less.

\section{Results}

\subsection{Area of Allotment Gardens}

There are 86 allotment gardens in Poznań. They are managed by the Polish Association of Allotment Gardeners. The total area of all allotment gardens in Poznan is 808.3 ha, where 18,440 individual allotment gardens occupy 620.2 ha (Polish Association of Allotment Gardeners, District Board in Poznań). The area of allotment gardens in Poznań is more than $50 \%$ larger than that of all green spaces managed by the Municipal Greenery Administration in Poznań, and it is more than twice as large as the area of city parks alone. The allotment gardens occupy $85 \%$ of the area of street greenery administered by the Green Space Department and City Roads Administration in Poznań. In comparison with sports and recreational areas belonging to the Poznan Sports and Recreation Centres and green spaces managed by the Department of Transport and Green Space, Poznań City Council, allotment gardens occupy an area that is over thirteen and almost forty times larger, respectively. The area of the allotment gardens was also compared with the area of forests located within the city limits of Poznan. The research showed that the area of the allotment gardens was equal to over $30 \%$ of the area of municipal forests in Poznan managed by the Poznan Forest Administration and over $60 \%$ of forests within the city limits of Poznań which are under the administration of the State Forests. The structure of Poznań's urban greenery is shown in Table 2. If the areas of individual types of green space in Poznań per capita are taken into consideration, allotment gardens rank fourth $\left(15.0 \mathrm{~m}^{2}\right.$ per capita), following the forests of the Poznan Forest Administration $\left(47.5 \mathrm{~m}^{2}\right)$ and the State Forests $\left(23.2 \mathrm{~m}^{2}\right)$ and the street greenery $\left(17.7 \mathrm{~m}^{2}\right)$. The areas of individual types of green space in Poznań per capita are shown in Table 3.

Table 2. The structure of green spaces in Poznań (2017).

\begin{tabular}{ccc}
\hline Managing Institutions & Form of Green Space & Area (ha) \\
\cline { 2 - 3 } $\begin{array}{c}\text { Poznań Municipal Greenery } \\
\text { Administration }\end{array}$ & Parks & 327.5 \\
\cline { 2 - 3 } & Green squares & 96.2 \\
\cline { 2 - 3 } & Cemeteries & 2.0 \\
\cline { 2 - 3 } $\begin{array}{c}\text { Green Space Department, } \\
\text { City Roads Administration }\end{array}$ & Total & 87.0 \\
\hline \multirow{2}{*}{$\begin{array}{c}\text { Poznań Sports and Recreation Centres } \\
\text { Department of Transport and Green Space, Poznań City Council }\end{array}$} & 512.7 \\
\hline \multicolumn{2}{c}{ Poznań Forest Administration } \\
\hline \multicolumn{2}{c}{ State Forests } \\
\hline \multicolumn{2}{c}{ Other forests } \\
\hline
\end{tabular}


Table 3. The area of green space in Poznań per capita $\left(\mathrm{m}^{2}\right)$ (2017).

\begin{tabular}{cc}
\hline Form of Green Space & Area per Capita $\mathbf{( m}^{\mathbf{2}} \mathbf{)}$ \\
\hline Allotment gardens & 15.0 \\
\hline Parks & 6.1 \\
\hline Green squares & 1.8 \\
\hline Cemeteries & 0.0 \\
\hline Unarranged green space & 1.6 \\
\hline Road greenery & 17.7 \\
\hline Green space under administration of Department of & 1.1 \\
\hline Transport and Green Space, Poznań City Council & 0.4 \\
\hline Poznań Forest Administration & 47.5 \\
\hline State Forests & 23.2 \\
\hline Other forests & 8.1 \\
\hline Source: & \\
\hline
\end{tabular}

Source: The author's compilation based on the data of the GUS Central Statistical Office (2017).

\subsection{Location of Individual Allotment Gardens in Relation to Their Surroundings}

The functional and spatial analysis of selected allotment gardens in Poznań is shown in Table 4. The most common functional and spatial category in the vicinity of Poznań allotment gardens is other urban greenery, which was found in 81 allotment gardens. The other five allotment garden types are located in the immediate vicinity of other allotment gardens, which are also elements of urban green space (Figure 1). The second most common environment was surface waters, accounting for $37.2 \%$ of all allotment gardens in Poznań. The third most common category was industrial areas, accounting for $33.7 \%$, followed by airports, constituting $31.4 \%$ of the allotment gardens. Railways were slightly less common near allotment gardens-almost 30\%. The least common category was sewage treatment plants-3.5\%. The second least common category was main roads, accounting for $9.3 \%$ of the allotment gardens. The spatial analysis of the allotment gardens in Poznan showed that they were considerably dispersed in the urban structure of Poznan, which positively affects the natural system of the city. The vast majority, i.e., 81 allotment gardens, occupying an area of $781.2 \mathrm{ha}$, are located near other green spaces. The functional analysis of the surroundings of Poznan allotment gardens showed that the vast majority of them were components of the green recreation and nature corridors in Poznań.

Table 4. Functional and spatial analysis of family allotment gardens (all 86 existing gardens) in Poznań.

\begin{tabular}{ccc}
\hline Name of Allotment Garden & $\begin{array}{c}\text { Total Number of Allotment } \\
\text { Gardens with Criterion }\end{array}$ & $\begin{array}{c}\text { \% Allotment Gardens } \\
\text { in Poznań }\end{array}$ \\
\hline Urban greenery $<200 \mathrm{~m}$ & 81 & 94.2 \\
\hline Surface waters $<300 \mathrm{~m}$ & 32 & 37.2 \\
\hline Main roads $>200 \mathrm{~m}$ & 8 & 9.3 \\
\hline Railways $<500 \mathrm{~m}$ & 25 & 29.1 \\
\hline Industrial zones $<500 \mathrm{~m}$ & 29 & 33.7 \\
\hline Airports $<1000 \mathrm{~m}$ & 27 & 31.4 \\
\hline Sewage treatment plants $<500 \mathrm{~m}$ & 3 & 3.5 \\
\hline
\end{tabular}




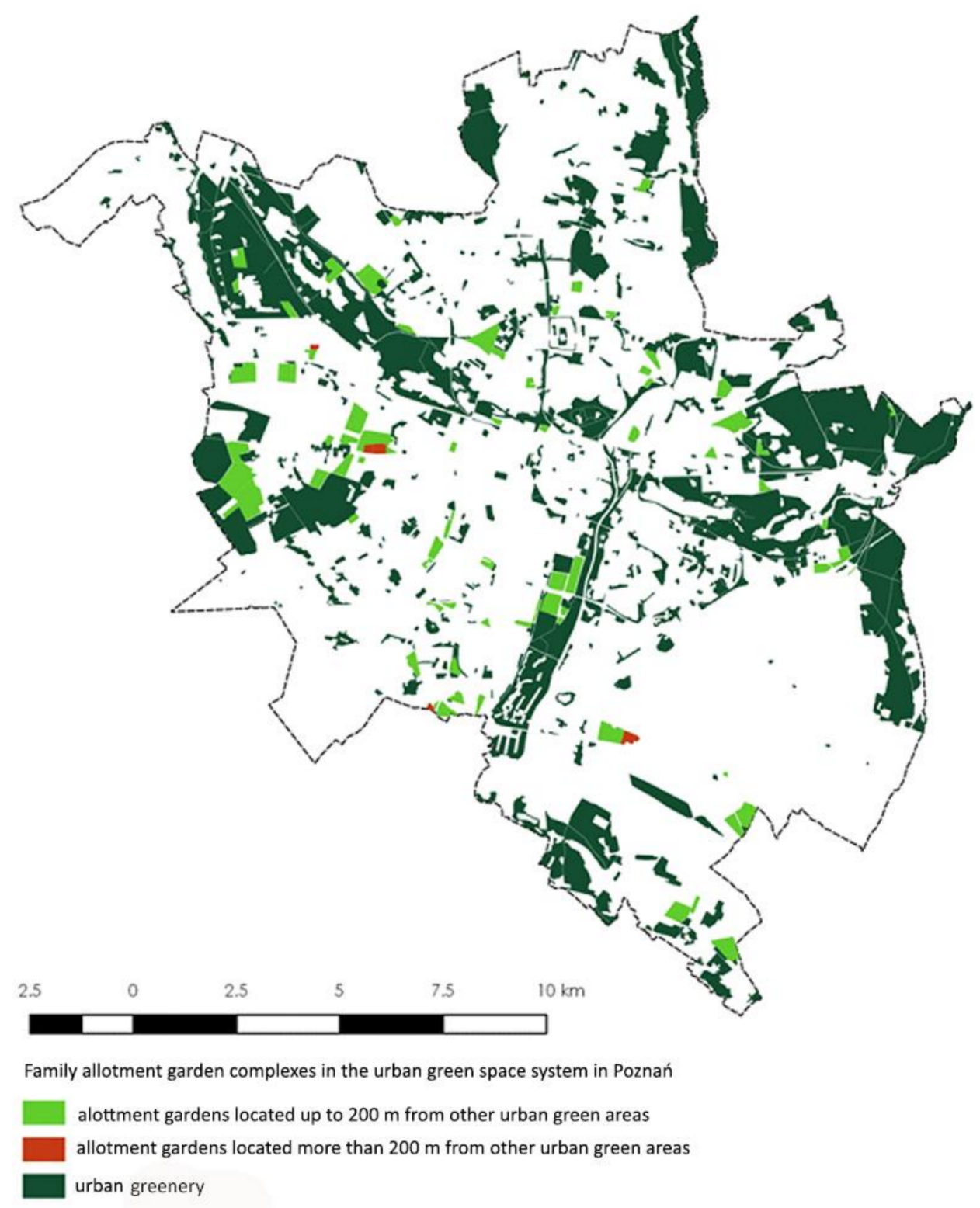

Figure 1. Allotment gardens in the urban green space system in Poznań.

3.3. Classification of Allotment Gardens According to Their Significance in the Urban Green Space System in Poznan

The classification of allotment gardens according to their significance in the urban green space system in Poznan is shown in Figure 2. The classification is visualized in Figure 3. The analysis showed that only one allotment garden was included in the first class, which means it is of very high significance to the urban green space system in Poznan. On the other hand, four allotment gardens were included in the fourth class, which means they are of very low significance to the urban green space system in Poznań. A majority of the garden allotments (55 allotments, 64\% of all allotment gardens in Poznań) were included in the third class, which means they are of low significance to the urban green space system in Poznan. The remaining 26 allotment gardens (over 30\% of all allotment gardens in Poznań) were included in the second class, which means they are of high significance to the urban green space system in Poznan. The majority of allotment gardens that are of very high or high significance to the urban green space system in Poznan are located in the southwest of the city. On the other hand, in the northwest of the city, there are the most allotment gardens of very low or low significance to the urban green space system in Poznań. 


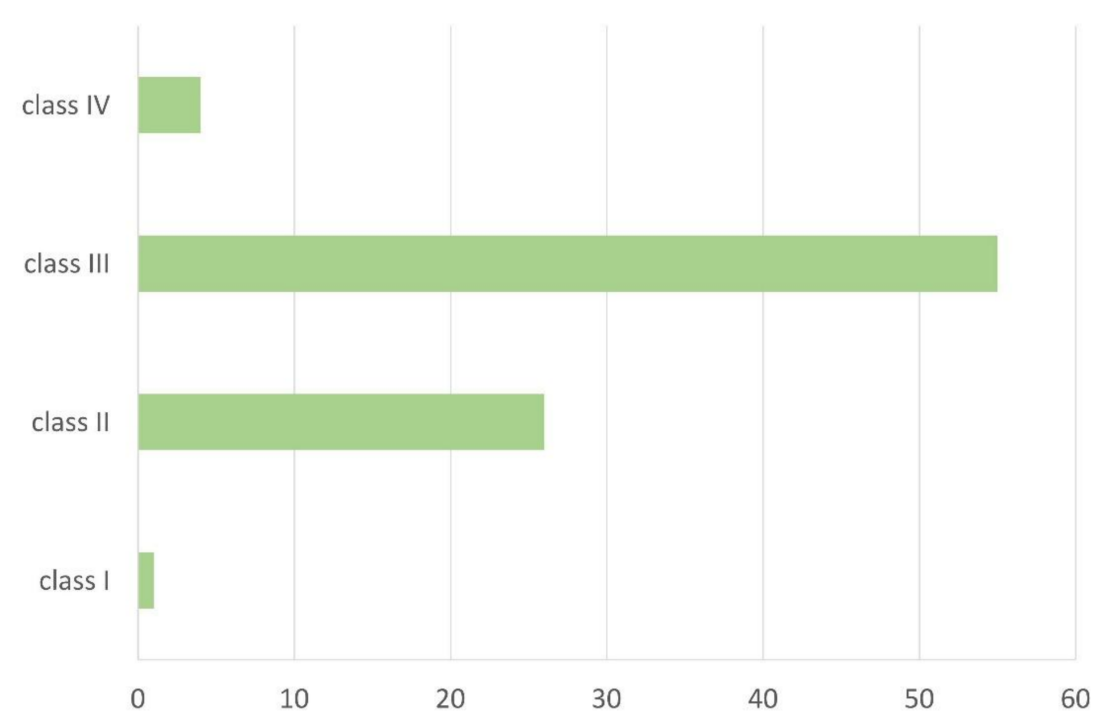

Figure 2. The number of allotment gardens in individual classes.

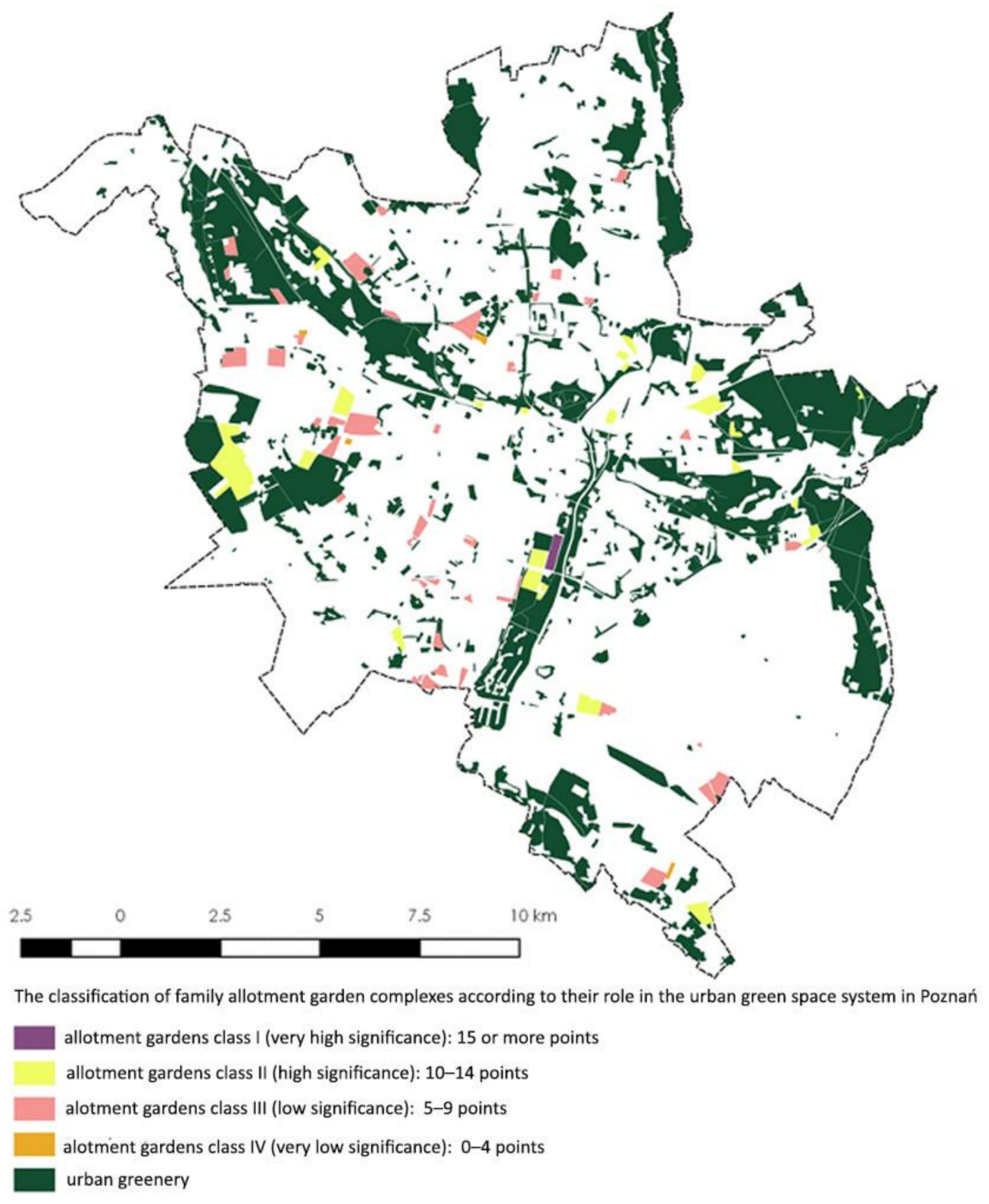

Figure 3. The classification of allotment gardens according to their significance in the urban green space system in Poznań. 


\subsection{Spatial Policy of the City}

According to the Poznań SUiKZP [43], 24 allotment gardens, constituting almost 28\% of all allotment gardens in Poznan, are part of the structural green wedges, which are components of the ring-wedge greenery system in Poznan. The current use of 65 allotment gardens-almost 700 ha (almost 75.6\% of all allotment gardens in Poznań)—will not change. Nine allotment gardens, i.e., almost $11 \%$ of Poznańs allotment gardens, which occupy over 35 ha are planned to be liquidated. New allotment gardens which are planned to compensate for those to be liquidated will be more than 5 ha smaller ( 30 ha) than the current ones. The land use of over 105 ha with 12 allotment gardens (14\% of all allotment gardens in Poznań) will change partly. This means that not all of the allotments will be liquidated.

The data from the SUiKZP [43] were compared with the classification of allotment gardens in terms of their significance for the urban green space system in Poznan. The analysis showed that two allotment gardens (with a total area of $17.1 \mathrm{ha}$ ) of high significance for the urban green space system (class II), five allotment gardens (with a total area of 16.4 ha) of low significance (class III) and one allotment garden (1.9 ha) of very low significance (class IV) will be liquidated. Partial liquidation is planned for one allotment garden $(24.7 \mathrm{ha}$ ) of high significance (class II) for the urban green space system, nine allotment gardens (with a total area of 77.2 ha) of low significance (class III) and one allotment garden ( 3.9 ha) of very low significance (class IV). The comparative analysis of the data from the SUiKZP [43] and the classification of allotment gardens showed that the vast majority of gardens to be liquidated are of low (14 allotment gardens-93.6 ha) or very low significance (two allotment gardens- $5.8 \mathrm{ha}$ ) for the urban green space system in Poznań.

\section{Discussion}

The significance of allotment gardens in the spatial structure of cities depends on the development trends and policies adopted by the authorities. The analysis of spatial planning documents in Polish cities showed that the existence of urban allotment gardens is at risk [44]. In the next few years or several decades, they may disappear or be moved to the outskirts. If allotment gardens are moved to more and more distant suburban zones, it will be more and more difficult for users to reach them. They will have to spend more time and money to reach these places. Consequently, allotment gardens may lose their traditional nature and change into suburban holiday homes because the growing of fruit and vegetables requires frequent and regular visits. Teuber et al. [45] researched allotment gardens located inside and outside cities in southwest Germany. The research showed that recreation and leisure were more important than the desire to grow crops as the reasons motivating owners to have an allotment located outside the city. On the other hand, the growing of fruit and vegetables was more important for the users of allotment gardens located in the city. In view of the fact that, both in Poland and other European countries [46], the vast majority of allotment garden users are old-age pensioners [43], most of them are likely to quit gardening. According to da Silva et al. [27], the production of fruit and vegetables particularly motivates less affluent people to have a garden allotment. For this group of residents, it is important that they can easily access their allotment gardens by public transport or bicycle. They will not be able to do so if allotment gardens are located on the outskirts of the city. On the other hand, urban planners from Western Europe believe that allotment gardens, as objects of general city importance and requiring large spaces, should be established at a greater distance from residential districts, usually outside the city. The reason for such location is usually high land prices. Therefore, good access conditions must be a compensation for the large distance of the gardens from the city [47].

In view of the increasing urbanization pressure, which reduces bioactive areas in cities, it is a priority to preserve allotment gardens due to climate changes and the need to adapt cities to them. Allotment gardens may significantly complement the spatial structure of the urban green space system [15]. 
The research showed that allotment gardens in Poznan are important areas and spaces in the urban greenery system in Poznan. However, it is disturbing that, according to the SUiKZP [43], the area of completed and planned total liquidations of allotment gardens in Poznan is 62 ha, whereas according to local spatial development plans, it is 37 ha. In both cases these areas are larger than the area of new allotment gardens (about 30 ha) which are planned to be established to compensate for the liquidated ones. This means that the area of allotment gardens in Poznan will gradually decrease. Moreover, the new allotment gardens, which are supposed to replace the liquidated ones, are located on the northern and southern outskirts of the city.

The decreasing area of allotment gardens in cities is a problem not only in Poznan, but also in other cities. For example, in Leicester, United Kingdom, the area of allotment gardens has been gradually decreasing since the 1950s, although in recent years the interest in urban horticulture and production of crops for one's own needs has been growing [28]. This trend can be observed throughout the UK $[48,49]$. The period when the area of allotment gardens began to decrease resulted from the local economic, social and political specificity. In post-communist countries, the area of allotment gardens began to decrease after the period of changes in the political and economic system in the 1990s [15]. This trend could also be observed in Poznań.

Allotment gardens are multifunctional urban green spaces. Over the centuries, the functions of allotment gardens have been changing as a result of socioeconomic changes. Traditionally used allotment gardens are the most important element of urban agriculture in Poland. Users can grow fruits and vegetables locally and thus shorten the path of food 'from field to plate'. Allotment gardens are important spaces which may ensure the nutritional self-sufficiency of cities in the future. For this to happen, allotment gardens should be designed in conjunction with housing construction. It is most advantageous to connect them via walking paths to a larger housing unit (15-minute pedestrian access isoprotection or 20-minute public transport access iso-protection). It is suggested to establish gardens with an area of 3-15 ha as larger gardens make administration more difficult and may constitute a spatial barrier. Solutions should be sought that reconcile two contradictory tendencies, i.e., maintaining the intimacy of private plots and making selected parts of the garden available for general use without disturbing its functioning [47]. The inventory study showed that the facilities and equipment in over $50 \%$ of the allotment gardens mainly served recreational purposes. The allotment gardens of mixed use, i.e., recreation and cultivation, were the second most common group-almost $27 \%$ of all allotment gardens inventoried. The allotment gardens used only for cultivation were the least common group - their share was slightly greater than 1.5\% [44]. Recreation and production are the leading functions of allotment gardens and other forms of urban gardening. It is also common in other countries, e.g., Germany [45], France, Canada [50] and Portugal [27].

The functional and spatial analysis showed that as much as $81.2 \%$ of all allotment gardens in Poznan are located near other types of urban greenery, together with which they could create an integrated system of recreational corridors. Despite the convenient location and high recreational potential of the allotment gardens in Poznan, as much as 93\% of them are inaccessible to the general public [44].

Allotment gardens have a significant share of and strategic location in the area of Poznan-mainly in the vicinity of green wedges (increasing their surface and connecting them with other green spaces) and densely built-up areas. Although they are accessible only to a narrow group of users, they are important green spaces with specific functions which cannot be replaced by public green spaces. In order to maintain the current location of allotment gardens in cities, where they can function as wildlife and recreational corridors, it is necessary to change the restricted access to them and maximize the number of direct users of the allotment greenery, especially due to the fact that recreation and leisure are currently the dominant functions of allotment gardens [51]. Increasing access to general use zones in allotment gardens, i.e., squares and alleys, is a compromise solution which could improve their social perception and help to preserve them in cities. The example 
of the allotment garden colony on Libenská Island in Prague proves that actions aimed at giving city residents more access to allotment gardens can effectively help to maintain these green spaces in cities [15]. However, it is necessary to take a wide range of actions to make allotment gardens generally accessible green spaces so as to enable the coexistence of garden users and other city inhabitants and to reconcile their interests.

In the past, many of the gardens were located in the peripheral zone of the city, and due to the urban sprawl, some of them are located in highly urbanized areas. The authorities of many Polish cities often consider liquidating some allotment gardens and allocating the income from their sale to the municipal budget [52]. In addition, private development companies exert a lot of pressure on urban planning, which often leads to violation of the stability, continuity and compactness of urban greenery systems. It is necessary to counteract these phenomena through rational and sustainable management of the multifunctional resources of allotment gardens. In the scale of a dynamically changing city, a planning tool is necessary that will allow one to easily classify allotment gardens as an important element of green areas.

Szkup [53] attempted to classify allotment gardens based on their individual features. In our method, we merged the classification based on individual features of allotment gardens to create a comprehensive valuation of their significance in a city green space system for the purposes of spatial planning. In the case of Poznań, a very important feature was the location of the allotment gardens close to green wedges as the most important structure of the urban green space system of the city. In other cities, reference should be made to the location of important and sustainable elements of green areas (e.g., river valleys and municipal forest complexes).

A limitation of the conducted study, and thus the method used, apart from adapting to the needs of other cities is the necessity to constantly monitor and update the data due to the variability of the adopted criteria in time (i.e., age, area and surroundings of the allotment garden). In future studies, the classification method could be extended by valorizing the neighborhood in terms of residential, educational, sports, service and hospital areas, which would allow for assessing the significance of allotment gardens in the context of not only green area systems but also the functional and spatial structure of the city.

\section{Conclusions}

I. The study showed that allotment gardens are important areal and spatial elements of the green space system in Poznań. The occurrence of allotment gardens in green wedges is essential as they are the most important and sustainable spatial structures of the urban greenery system. The current use of almost $75.6 \%$ of all allotment gardens in Poznań will not change according to the spatial planning documents.

II. A classification and valuation method was used in the study to determine the role of individual allotment gardens in the green space system in Poznań. Over $30 \%$ of the allotment gardens were of high significance in the green space system of the city. The majority of allotment gardens were identified in class III (low significance).

III. The analysis of urban planning documents showed that the area of allotment gardens in Poznań will be decreasing. There are also plans to liquidate the allotment gardens that were valuated as facilities of high significance to the urban green space system. Taking into account the results of the presented classification, these plans should be revised. In the context of the vital investment needs of the city, the functions of the allotment gardens that are least valuable for the city green space system (class IV) may be changed.

IV. This classification method based on individual internal and external features of allotment gardens creates a comprehensive valuation of their significance in a city green space system for the purposes of spatial planning. Use of the developed classification when creating planning documents could influence the decision- 
making process regarding the liquidation of allotment gardens and the preservation of the most valuable objects.

Author Contributions: Conceptualization, D.D., L.B., A.W. and M.S.; methodology, D.D., A.W. and M.S.; software, D.D.; validation, L.B., A.W., D.D. and M.S.; formal analysis, D.D.; investigation, D.D.; resources, D.D.; data curation, D.D.; writing-original draft preparation, D.D., L.B. and A.W.; writing, D.D., L.B. and A.W.; writing-review and editing, A.W., L.B., D.D. and M.S.; visualization, D.D.; supervision, A.W. and L.B.; project administration A.W., L.B. and M.S.; funding acquisition, L.B. and M.S. All authors have read and agreed to the published version of the manuscript.

Funding: The publication was co-financed within the framework of Ministry of Science and Higher Education programme as "Regional Initiative Excellence" in years 2019-2022, Project No. 005/RID/2018/19.

Institutional Review Board Statement: Not applicable.

Informed Consent Statement: Not applicable.

Data Availability Statement: Study did not report any data.

Conflicts of Interest: The authors declare no conflict of interest.

\section{References}

1. Poniży, L.; Stachura, K. Future of Allotment Gardens in the Context of City Spatial Policy - A Case Study of Poznań. Quaest. Geogr. 2017, 36, 121-127. [CrossRef]

2. Buchel, S.; Frantzeskaki, N. Citizens' Voice: A Case Study about Perceived Ecosystem Services by Urban Park Users in Rotterdam, the Netherlands. Ecosyst. Serv. 2015, 12, 169-177. [CrossRef]

3. Jim, C.; Chen, W.Y. Recreation-amenity Use and Contingent Valuation of Urban Greenspaces in Guangzhou, China. Landsc. Urban Plan. 2006, 75, 81-96. [CrossRef]

4. Trembecka, A.; Kwartnik-Pruc, A. An Analysis of the Changes in the Structure of Allotment Gardens in Poland and of the Process of Regulating Legal Status. Sustainability 2018, 10, 3829. [CrossRef]

5. Biglin, J. Embodied and Sensory Experiences of Therapeutic Space: Refugee Place-Making Within an Urban Allotment. Heal. Place 2020, 62, 102309. [CrossRef] [PubMed]

6. Gill, S.E.; Handley, J.F.; Ennos, A.R.; Pauleit, S. Adapting Cities for Climate Change: The Role of the Green Infrastructure. Built Environ. 2007, 33, 115-133. [CrossRef]

7. Tratalos, J.; Fuller, R.; Warren, P.H.; Davies, R.G.; Gaston, K.J. Urban Form, Biodiversity Potential and Ecosystem Services. Landsc. Urban Plan. 2007, 83, 308-317. [CrossRef]

8. Malinowska, E.; Szumacher, I. Rola ogrodów działkowych W Krajobrazie lewobrzeżnej Warszawy. Problemy Ekologii Kra-Jobrazu 2008, 22, 139-150.

9. Wise, S. Green Infrastructure Rising: Best Practices in Stormwater Management; American Planning Association: Chicago, IL, USA, 2008; pp. 1-7.

10. Pauleit, S.; Duhme, F. Assessing the Environmental Performance of Land Cover Types for Urban Planning. Landsc. Urban Plan. 2000, 52, 1-20. [CrossRef]

11. Müller, N.; Werner, P.; Kelcey, J.G. Urban Biodiversity and Design; John Wiley \& Sons: Hoboken, NJ, USA, 2010.

12. Hostetler, M.; Allen, W.; Meurk, C. Conserving Urban Biodiversity? Creating Green Infrastructure Is Only the First Step. Landsc. Urban Plan. 2011, 100, 369-371. [CrossRef]

13. Frey, D.; Moretti, M. A Comprehensive Dataset on Cultivated and Spontaneously Growing Vascular Plants in Urban Gardens. Data Brief 2019, 25, 103982. [CrossRef] [PubMed]

14. Szulczewska, B.; Cieszewska, A.; Prove, C. Urban Agriculture and "early birds" Initiatives in Warsaw. Problemy Ekologii Krajobrazu 2013, 36, 155-165.

15. Spilková, J.; Vágner, J. The Loss of Land Devoted to Allotment Gardening: The Context of the Contrasting Pressures of Urban Planning, Public and Private Interests in Prague, Czechia. Land Use Policy 2016, 52, 232-239. [CrossRef]

16. Sowińska-Świerkosz, B.; Michalik-Śnieżek, M.; Bieske-Matejak, A. Can Allotment Gardens (AGs) Be Considered an Example of Nature-Based Solutions (NBS) Based on the Use of Historical Green Infrastructure? Sustainability 2021, 13, 835. [CrossRef]

17. GUS Główny Urząd Statystyczny (Central Statistical Office.) Bank Danych Lokalnych. Available online: https://bdl.stat.gov.pl/ BDL/dane/teryt/Tablica (accessed on 18 August 2020).

18. Kim Sa Polscy działkowcy? Badanie Wykonane Przez Krajowa Radę Polskiego Zwiąku Działkowców Przy współudziale okręgowych zarząów PZD I zarząów ROD; Krajowa Rada Polskiego Związku Działkowców: Warszawa, Poland, 2012. Available online: http:/ / pzd.pl/archiwum/strona.php?421 (accessed on 18 August 2020).

19. Szczepańska, M. Family Allotment Gardens - the Case of the Poznań Agglomeration. Eur. XXI 2017, 32, 71-87. [CrossRef]

20. Lewińska, J. Klimat Miasta; IGPiK: Kraków, Poland, 2000.

21. Pawlikowska-Piechotka, A. Tradycja ogrodów działkowych W Polsce; Novae Res - Wydawnictwo Innowacyjne: Gdynia, Poland, 2010. 
22. Kronenberg, J.; Bergier, T.; Lisicki, P. Ustugi ekosystemów W Praktyce a Ogrody działkowe. In Ogrody działkowe W Mi-Astach-Bariera Czy wartość? Kosmala, M., Ed.; PZiTS Oddział Torun: Torun, Poland, 2013; pp. 158-168.

23. Barthel, S.; Folke, C.; Colding, J. Social-ecological Memory in Urban gardens-Retaining the Capacity for Management of Ecosystem Services. Glob. Environ. Chang. 2010, 20, 255-265. [CrossRef]

24. Urban Allotment Gardens in Europe. In Urban Allotment Gardens in Europe; Routledge: London, UK; New York, NY, USA, 2016; pp. 115-141. [CrossRef]

25. Cabral, I.; Keim, J.; Engelmann, R.; Kraemer, R.; Siebert, J.; Bonn, A. Ecosystem Services of Allotment and Community Gardens: A Leipzig, Germany Case Study. Urban For. Urban Green. 2017, 23, 44-53. [CrossRef]

26. Langemeyer, J.; Camps-Calvet, M.; Calvet-Mir, L.; Barthel, S.; Gómez-Baggethun, E. Stewardship of Urban Ecosystem Services: Understanding the value(s) of Urban Gardens in Barcelona. Landsc. Urban Plan. 2018, 170, 79-89. [CrossRef]

27. Silva, I.; Fernandes, C.; Castiglione, B.; Costa, L. Characteristics and Motivations of Potential Users of Urban Allotment Gardens: The Case of Vila Nova De Gaia Municipal Network of Urban Allotment Gardens. Urban For. Urban Green. 2016, 20 , 56-64. [CrossRef]

28. Edmondson, J.L.; Childs, D.; Dobson, M.; Gaston, K.J.; Warren, P.H.; Leake, J.R. Feeding a City - Leicester As a Case Study of the Importance of Allotments for Horticultural Production in the UK. Sci. Total Environ. 2020, 705, 135930. [CrossRef] [PubMed]

29. Young, C.; Hofmann, M.; Frey, D.; Moretti, M.; Bauer, N. Psychological Restoration in Urban Gardens Related to Garden Type, Biodiversity and Garden-Related Stress. Landsc. Urban Plan. 2020, 198, 103777. [CrossRef]

30. van der Jagt, A.P.; Szaraz, L.R.; Delshammar, T.; Cvejić, R.; Santos, A.; Goodness, J.; Buijs, A. Cultivating Nature-Based Solutions: The Governance of Communal Urban Gardens in the European Union. Environ. Res. 2017, 159, 264-275. [CrossRef] [PubMed]

31. Lee, J.H.; Matarrita-Cascante, D. The Influence of Emotional and Conditional Motivations on gardeners' Participation in Community (allotment) Gardens. Urban For. Urban Green. 2019, 42, 21-30. [CrossRef]

32. Urban Allotment Gardens in Europe; Routledge: London, UK, 2016; pp. 201-228. [CrossRef]

33. Viljoen, A.; Wiskerke, J.S.C. Sustainable Food Planning: Evolving Theory and Practice. In Sustainable Food Planning: Evolving Theory and Practice; Wageningen Academic Publishers: Wageningen, The Netherlands, 2012; pp. 479-494. [CrossRef]

34. Allotment Gardens Act of 13 December 2013 (Ustawa O Rodzinnych Ogrodach działkowych Dz.U 2014 Poz. 40). Available online: http:/ / isap.sejm.gov.pl/isap.nsf/download.xsp/WDU20140000040/U/D20140040Lj.Pdf (accessed on 19 April 2021).

35. Nature Conservation Act of 16 April 2004 (Ustawa O Ochronie Przyrody Dz.U. 2004 Nr 92 Poz. 880). Available online: http:/ /isap.sejm.gov.pl/isap.nsf/download.xsp/WDU20040920880/T/D20040880L.Pdf (accessed on 19 April 2021).

36. Kacprzak, E.; Maćkiewicz, B.; Szczepańska, M. Legal Regulations and the Development of German and Polish Allotment Gardens in the Context of the Production Function. Ruch-Prawniczy Èkon. i Socjol. 2020, 82, 197-215. [CrossRef]

37. Ricci, J.M.P.; Conrad, E. Exploring the Feasibility of Setting up Community Allotments on Abandoned Agricultural Land: A Place, People, Policy Approach. Land Use Policy 2018, 79, 102-115. [CrossRef]

38. Anderson, E.C.; Egerer, M.H.; Fouch, N.; Clarke, M.; Davidson, M.J. Comparing Community Garden Typologies of Baltimore, Chicago, and New York City (USA) to Understand Potential Implications for Socio-Ecological Services. Urban Ecosyst. 2019, 22, 671-681. [CrossRef]

39. Urban Atlas. Available online: https://land.copernicus.eu/local/Urban-Atlas. (accessed on 20 July 2020).

40. Dabrowska-Milewska, G. Standardy Urbanistyczne Dla terenów Mieszkaniowych-Wybrane Zagadnienia. Architecturae Et Artibus 2010, 2, 17-31.

41. Dzikowska, A.; Krzemińska, A.; Zareba, A. Allotment Gardens As Significant Element Integrating Greenery System of the City. In Proceedings of the IOP Conference Series: Earth and Environmental Science, Prague, Czech Republic, 3-7 September 2018; IOP Publishing: Prague, Czech Republic, 2019; Volume 221, p. 012121. [CrossRef]

42. Raszeja, E.; Gałecka-Drozda, A. Współczesna Interpretacja Idei poznańskiego Systemu Zieleni Miejskiej W kontekście Strate-Gii Miasta zrównoważonego. Studia Miejskie 2015, 19, 75-86.

43. Study of Conditions and Directions of Spatial Development (SUiKZP) 2014, Municipal Urbanism Workshop (Miejska Pra-Cownia Urbanistyczna Poznan). Available online: www.mpu.pl/plany.Php (accessed on 6 October 2018).

44. Dymek, D. Użytkowanie I Kierunki Rozwoju Rodzinnych ogrodów działkowych Na przykładzie Poznania. Ph.D. Thesis, University of Life Sciences in Poznań, Poznań, Poland, 2019.

45. Teuber, S.; Schmidt, K.; Kühn, P.; Scholten, T. Engaging with Urban Green Spaces-A Comparison of Urban and Rural Allotment Gardens in Southwestern Germany. Urban For. Urban Green. 2019, 43, 126381. [CrossRef]

46. Domene, E.; Saurí, D. Urbanization and Class-Produced Natures: Vegetable Gardens in the Barcelona Metropolitan Region. Geoforum 2007, 38, 287-298. [CrossRef]

47. Duś, E. Miejsce I Rola ogrodów działkowych W Przestrzeni Miejskiej. Geographia. Studia Et Dissertationes 2011, 33, 79-100.

48. Scott, A.; Dean, A.; Barry, V.; Kotter, R. Places of Urban Disorder? Exposing the Hidden Nature and Values of an English Private Urban Allotment Landscape. Landsc. Urban Plan. 2018, 169, 185-198. [CrossRef]

49. Dobson, M.C.; Edmondson, J.L.; Warren, P.H. Urban Food Cultivation in the United Kingdom: Quantifying Loss of Allotment Land and Identifying Potential for Restoration. Landsc. Urban Plan. 2020, 199, 103803. [CrossRef]

50. Pourias, J.; Aubry, C.; Duchemin, E. Is Food a Motivation for Urban Gardeners? Multifunctionality and the Relative Importance of the Food Function in Urban Collective Gardens of Paris and Montreal. Agric. Hum. Values 2016, 33, 257-273. [CrossRef] 
51. Maćkiewicz, B.; Szczepańska, M.; Kacprzak, E.; Fox-Kämper, R. Between Food Growing and Leisure: Contemporary Allotment Gardeners in Western Germany and Poland. DIE ERDE J. Geogr. Soc. Berlin 2021, 152, 33-50. [CrossRef]

52. Szkup, R.; Pytel, S. Ogrody Działkowe (ROD) W Przestrzeni dużego Miasta. Przykład Łodzi. Prace Komisji Krajobrazu Kulturowego 2016, 32, 109-124.

53. Szkup, R. Użytkowanie Rodzinnych ogrodów działkowych (ROD) Przez społeczność wielkomiejska, przykład Łodzi; Wydawnictwo Uniwersytetu Łódzkiego: Łódź, Poland, 2013. 